\title{
PERAN TEKNOLOGI DAN INFORMASI DALAM MENINGKATKAN INOVASI PENDIDIKAN
}

\author{
Muhammad Wafi \\ Email: 1810111310006@mhs.ulm.ac.id \\ Program Studi Pendidikan Sejarah Fakultas Keguruan dan Ilmu Pendidikan \\ Universitas Lambung Mangkurat \\ Banjarmasin
}

\begin{abstract}
Abstrak
Konsep Inovasi pendidikan dimana Inovasi mengingatkan pada istilah invention dan discovery. Invention adalah penemuan sesuatu yang benar-benar baru, artinya hasil karya manusia. Adapun discovery adalah penemuan sesuatu (benda yang sebenarnya telah ada sebelumnya). Seoarang guru harus memiliki sifat yang inovatif karena hal tersebut dapat memungkinkan seorang guru bisa mampu menghadapi situasi dan kondisi seperti apapun agar pembelajaran akan tetap berjalan secara efektif. Meningkatnya teknologi di era globalisasi yang serba modern ini bisa kita terapkan pada dunia pendidikan sebagai fasilitas lebih dan serba canggih untuk memperlancar proses pembelajaran yang disampaikan. Disini pentingnya teknologi untuk selalu diikuti perkembangannya. Penggunaan teknologi terbukti dapat meningkatkan minat belajar anak karena tampilan yang lebih menarik sehingga akan terhindar dari rasa jenuh selama mengikuti pelajaran. Adanya informasi yang digunakan untuk media pembelajaran dapat berdampak positif bagi para siswa, yaitu mereka bisa lebih mudah dalam mencari informasi yang diperlukan selama proses pembelajaran.
\end{abstract}

Kata Kunci : inovasi pendidikan, teknologi informasi, guru. 


\section{PENDAHULUAN}

Konsep Inovasi pendidikan dimana Inovasi mengingatkan pada istilah invention dan discovery. Invention adalah penemuan sesuatu yang benar-benar baru, artinya hasil karya manusia. Adapun discovery adalah penemuan sesuatu (benda yang sebenarnya telah ada sebelumnya).

Inovasi dapat diartikan usaha menemukan benda yang baru dengan jalan melakukan kegiatan (usaha) invention dan discovery. Dalam kaitan ini, Ibrahim (1989) mengatakan bahwa inovasi adalah penemuan yang dapat berupa sesuatu ide, barang, kejadian, metode yang diamati sebagai sesuatu hal yang baru bagi seseorang atau sekelompok orang (masyarakat). Inovasi dapat berupa hasil dari invention atau discovery. Inovasi dilakukan dengan tujuan tertentu atau untuk memecahkan masalah (Rusdiana, 2014: 44).

Inovasi sering diartikan pembaharuan, penemuan dan ada yang mengaitkan dengan modernisasi. Perubahan dan inovasi, keduanya sama dalam hal memiliki unsur yang baru atau lain dari sebelumnya. Inovasi berbeda dari perubahan karena dalam inovasi dalam unsur kesengajaan. Pembaharuan misalnya, dalam hal pembaharuan kebijakan pendidikan mengandung unsur kesengajaan dan pada umumnya istilah pembaharuan dapat disamakan dengan inovasi. Menurut Nicholls, penggunaan kata perubahan dan inovasi sering tumpang tindih. Pada dasarnya, inovasi adalah ide, produk, kejadian, atau metode yang dianggap baru bagi seseorang atau sekelompok orang atau unit adopsi yang lain, baik hasil invensi maupun hasil discovery.

Nicholls menekankan perbedaan antara perubahan (change) dengan inovasi (innovation) sebagaimana dikatakannya di atas, bahwa perubahan mengacu pada kelangsungan penilaian, penafsiran, dan pengharapan kembali dalam perbaikan pelaksanaan pendidikan yang ada yang dianggap sebagai bagian aktivitas yang biasa. Adapun inovasi menurutnya mengacu pada ide, objek atau praktik sesuatu yang baru oleh seseorang atau sekelompok orang yang bermaksud untuk memperbaiki tujuan yang diharapkan.

Inovasi pendidikan adalah inovasi untuk memecahkan masalah dalam pendidikan. Inovasi pendidikan mencakup hal-hal yang berhubungan dengan komponen sistem pendidikan, baik dalam arti sempit, yaitu tingkat lembaga pendidikan, maupun arti luas, 
yaitu sistem pendidikan nasional. Inovasi dalam dunia pendidikan dapat berupa apa saja, produk ataupun sistem. Produk misalnya, seorang guru menciptakan media pembelajaran mock up untuk pembelajaran. Sistem misalnya, cara penyampaian materi di kelas dengan tanya jawab ataupun yang lainnya yang bersifat metode. Inovasi dapat dikreasikan sesuai pemanfaatannya, yang menciptakan hal baru, memudahkan dalam dunia pendidikan, serta mengarah pada kemajuan. Inovasi di sekolah, terjadi pada sistem sekolah yang meliputi komponen-komponan yang ada. Di antaranya adalah sistem pendidikan sekolah yang terdiri atas kurikulum, tata tertib, dan manajemen organisasi pusat sumber belajar. Selain itu, yang lebih penting adalah inovasi dilakukan pada sistem pembelajaran (yang berperan di dalamnya adalah guru) karena secara langsung yang melakukan pembelajaran di kelas ialah guru. Keberhasilan pembelajaran sebagian besar tanggung jawab guru.

\section{PERAN GURU SEBAGAI SEBUAH PROFESI}

Seoarang guru harus memiliki sifat yang inovatif karena hal tersebut dapat memungkinkan seorang guru bisa mampu menghadapi situasi dan kondisi seperti apapun agar pembelajaran akan tetap berjalan secara efektif.

Bentuk inovasi yang dapat dilakukan guru dalam berinovasi di era teknologi informasi adalah pemahaman dalam penggunaan strategi dalam pembelajaran. Salah satu faktor yang ikut menentukan efektivitas pelaksanaan yang berinovasai oleh guru adalah ketepatan penggunaan strategi. Akan tetapi, memilih strategi yang tepat bukan pekerjaan yang mudah. Sukar untuk memilih satu strategi tertentu guna mencapai tujuan atau target perubahan sosial tertentu. seperti Strategi Fasilitatif dan Strategi Pendidikan.

Strategi fasilitatif digunakan untuk memperbaharui bidang pendidikan. Adanya kurikulum baru dengan pendekatan keterampilan proses misalnya, memerlukan perubahan atau pembaharuan kegiatan belajar mengajar. Jika untuk keperluan tersebut digunakan pendekatan fasilitatif, program pembaharuan yang dilaksanakan menyediakan berbagai macam fasilitas dan sarana yang diperlukan. Sekalipun demikian, fasilitas dan sarana itu tidak akan banyak bermanfaat dan menunjang perubahan jika guru atau pelaksana pendidikan sebagai sasaran perubahan tidak memahami masalah pendidikan yang dihadapi, tidak merasakan perlu adanya perubahan pada dirinya, tidak perlu atau tidak bersedia 
menerima bantuan dari luar atau dari yang lain, tidak memiliki kemauan untuk berpartisipasi dalam usaha pembaharuan. Demikian pula, seandainya dalam pembaharuan kurikulum disediakan berbagai macam fasilitas media instruksional dengan maksud agar pelaksanaan kurikulum baru dengan pendekatan keterampilan proses dapat lancar, ternyata para guru sebagai sasaran perubahan tidak memiliki kemampuan untuk menggunakan media, perlu diusahakan adanya kemampuan atau peranan yang baru, yaitu pengelola atau sebagai pemakai media institusional.

Strategi Pendidikan, Perubahan sosial didefinisikan sebagai pendidikan atau pengajaran kembali (re-education) (Rusdiana, 2014: 93). Pendidikan juga dipakai sebagai strategi untuk mencapai tujuan perubahan sosial. Dengan menggunakan strategi pendidikan, perubahan sosial dilakukan dengan cara menyampaikan fakta dengan maksud penggunaan fakta atau informasi untuk menentukan tindakan yang akan dilakukan. Dasar pemikirannya adalah manusia akan mampu untuk membedakan fakta serta memilihnya guna mengatur tingkah lakunya apabila fakta ditunjukkan kepadanya. Zaltman menggunakan istilah re-education dengan alasan bahwa dengan strategi ini memungkinkan seseorang untuk belajar lagi tentang sesuatu yang dilupakan yang sebenarnya telah dipelajarinya sebelum mempelajari tingkah laku atau sikap yang baru.

\section{GURU INDONESIA DAN TANTANGAN PROFESIONALISME}

Meningkatnya teknologi di era globalisasi yang serba modern ini bisa kita terapkan pada dunia pendidikan sebagai fasilitas lebih dan serba canggih untuk memperlancar proses pembelajaran yang disampaikan. Disini pentingnya teknologi untuk selalu diikuti perkembangannya.

Penggunaan teknologi terbukti dapat meningkatkan minat belajar anak karena tampilan yang lebih menarik sehingga akan terhindar dari rasa jenuh selama mengikuti pelajaran. Seperti di indonesia yang sebagian besar sekolah masih belum menggunakan teknologi dalam pendidikan.

Adanya informasi yang digunakan untuk media pembelajaran dapat berdampak positif bagi para siswa, yaitu mereka bisa lebih mudah dalam mencari informasi yang 
diperlukan selama proses pembelajaran. Media yang bisa digunakan adalah dengan menyediakan komputer dan internet di tiap-tiap sekolah.

Manfaat teknologi dalam dunia pendidikan antara lain ; a). Menambah informas sebagai sarana pendukung bagi siswa dan pendidik untuk mencari informasi yang lebih luas, selain menggunakan sumber dari buku dan media cetak, b). Meningkatkan kemampuan belajar dimana hal ini terjadi karena informasi yang ada di internet lebih update sehingga para siswa bisa dengan mudah mengakses informasi-informasi baru yang diperlukan, di bawah pengawasan guru, c). Memudahkan akses belajar, dimana proses pembelajaran dapat dipemudah dengan adanya teknologi dalam pendidikan. Misalkan guru dapat memberikan materi atau tugas belajar melalui email sehingga peserta didik bisa segera menyelesaikan dan mengumpukan tugas tersebut, d). Materi lebih menarik, penggunaan teknologi dalam pendidikan dapat membuat peserta didik lebih nyaman dan tidak terkesan jenuh atau monoton. Karena penyampaian informasi melalui teknologi cangging terlihat lebih variatif dan modern, e). Meningkatkan minat belajar, informasi dan pengetahuan yang lebih lengkap serta akses yang mudah didapatkan dapat membuat siswa lebih minat dalam melaksanakan pembelajaran.

Contoh inovasi yang dapat dilakukan guru dalam proses pendidikan dengan berbasis pada teknologi informasi seperti electronic learning. Electronic learning (e.learning) pada hakekatnya adalah belajar atau pembelajaran melalui pemanfaatan teknologi komputer atau internet. Teknologi belajar seperti itu dapat juga disebut pembelajaran berbasis web (web based instruction). Pembahasan mengenai e-learning ini merupakan fokus utama dalam pembelajaran modul ini, oleh karena itu secara rinci sajian materi modul ini meliputi penjelasan tentang: konsep pembelajaran electronic learning, model pengembangan pembelajaran melalui internet, dan kemasan bahan belajar melalui teknologi informasi. 


\section{SIMPULAN}

Perkembangan teknologi dan informasi tidaak akan bisa lepas dari dunia ini, di bidang pendidikan pun sangat terasa dampaknya. Teknologi dan informasi juga membuat guru-guru sebagai tenaga pendidik harus bosa melakukan inovassi-inovasi yang mampu meningkatkan efektifitas dalam proses pembelajaran yang dimana hal tersebut akan sangat berpengaruh terhadap hasil belajar peserta didik. Teknologi dan informasi menyediakan segala yang diperlukan oleh tenaga pendidik untuk mengembangkan inovasi-inovasi yang bisa menciptakan kemajuan di bidang pendidikan. Inovasi sendiri merupakan ide-ide yang muncul guna kemajuan suatu bangsa dalam kanah pendidikan. 


\section{REFERENSI}

Anis, M. Z. A., Putro, H. P. N., Susanto, H., \& Hastuti, K. P. (2020). Historical Thinking Model in Achieving Cognitive Dimension of Indonesian History Learning. PalArch's Journal of Archaeology of Egypt/Egyptology, 17(7), 7894-7906.

Anis, M. Z. A., Susanto, H., \& Mardiani, F. (2021, February). Analysis of the Effectiveness of MPBH: The Mains of Mandai as a Saving Food in Banjarmasin Community. In The 2nd International Conference on Social Sciences Education (ICSSE 2020) (pp. 89-94). Atlantis Press.

Efendi, I., Prawitasari, M., \& Susanto, H. (2021). Implementasi Penilaian Pembelajaran Pada Kurikulum 2013 Mata Pelajaran Sejarah. Prabayaksa: Journal of History Education, 1(1), 21-25.

http://file.upi.edu/Direktori/DUAL-MODES/INOVASI_PENDIDIKAN/Modul_6Inovasi_Pembelajaran_Melalui_TIK.pdf Di akses tanggal 20 April 2021

Rusdiana. (2014). Konsep Inovasi Pendidikan. Bandung: Pustaka Setia

Susanto, H. (2020). Profesi Keguruan. Banjarmasin: FKIP Universitas Lambung Mangkurat.

Susanto, H., \& Akmal, H. (2018). Efektivitas Penggunaan Aplikasi Pembelajaran Berbasis Mobile Smartphone Sebagai Media Pengenalan Sejarah Lokal Masa Revolusi Fisik Di Kalimantan Selatan Pada Siswa Sekolah Menengah Atas. HISTORIA: Jurnal Program Studi Pendidikan Sejarah, 6(2), 197-206.

Susanto, H., Irmawati, I., Akmal, H., \& Abbas, E. W. (2021). Media Film Dokumenter Masuknya Islam Ke Nusantara dan Pengaruhnya Terhadap Keterampilan Berpikir Kritis Siswa. HISTORIA: Jurnal Program Studi Pendidikan Sejarah, 9(1). 